\title{
Warrants in Underwritten IPOs: The Alternative Investment Market (AIM) Experience
}

DOI:

10.1016/j.jcorpfin.2016.07.010

\section{Document Version}

Accepted author manuscript

Link to publication record in Manchester Research Explorer

\section{Citation for published version (APA):}

Khurshed, A., Kostas, D., \& Saadouni, B. (2016). Warrants in Underwritten IPOs: The Alternative Investment Market (AIM) Experience. Journal of Corporate Finance, 40, 97-109. https://doi.org/10.1016/j.jcorpfin.2016.07.010

\section{Published in:}

Journal of Corporate Finance

\section{Citing this paper}

Please note that where the full-text provided on Manchester Research Explorer is the Author Accepted Manuscript or Proof version this may differ from the final Published version. If citing, it is advised that you check and use the publisher's definitive version.

\section{General rights}

Copyright and moral rights for the publications made accessible in the Research Explorer are retained by the authors and/or other copyright owners and it is a condition of accessing publications that users recognise and abide by the legal requirements associated with these rights.

\section{Takedown policy}

If you believe that this document breaches copyright please refer to the University of Manchester's Takedown Procedures [http://man.ac.uk/04Y6Bo] or contact uml.scholarlycommunications@manchester.ac.uk providing relevant details, so we can investigate your claim.

\section{OPEN ACCESS}




\title{
Warrants in Underwritten IPOs: The Alternative Investment Market (AIM) Experience
}

\author{
Arif Khurshed $*^{\mathrm{a}}$ \\ (Arif.khurshed@manchester.ac.uk) \\ Dimitris Kostas ${ }^{b}$ \\ (Dimitris.Kostas.82@gmail.com)
}

\author{
Brahim Saadouni $^{\mathrm{a}}$ \\ (Brahim.Saadouni@manchester.ac.uk)
}

Forthcoming: Journal of Corporate Finance

\begin{abstract}
We examine the use of warrants as a part of underwriter compensation in IPOs listed on the Alternative Investment Market (AIM) of the London Stock Exchange. Our results show that, though warrant-issuing IPO firms are riskier, they are usually underwritten by reputable underwriters. Firms that are cash constrained at the time of their IPO are more likely to use warrants. Both market volatility and hot issue markets increase the likelihood of firms issuing warrants. We also find that warrant issuers are able to minimise their total costs of going public, even under a very light regulatory setting with regards non-cash compensation. They incur actual costs of $29.1 \%$, but would have incurred greater costs of $33.8 \%$ had they not issued warrants to their underwriters. Overall, our results support the cost minimisation explanation of the use of warrants by UK IPO firms.
\end{abstract}

Keywords: IPOs; Warrants; Brokers; Compensation; AIM

JEL classification: G320; G34; G38

${ }^{a}$ The authors are from the Accounting and Finance Group, Alliance Manchester Business School, University of Manchester, Booth Street East, Manchester, M15 6PB, UK.

${ }^{\mathrm{b}}$ Powertrain Finance Analyst, Ford Motors, Southend-on-Sea, UK

* Corresponding Author: Arif Khurshed, Phone: +44 161 2754475, Fax: +44 1612754023 


\section{Introduction}

The costs of going public are an important consideration for companies planning a listing on a stock exchange. For a typical IPO on the New York Stock Exchange (NYSE), the total direct costs of listing amount to nearly $8 \%$ of the gross proceeds. For IPOs on the London Stock Exchange (LSE), this figure can be as high as $13 \%$ (Kaserer and Schiereck, 2008). ${ }^{1}$ Of the various direct costs of going public, underwriter's compensation is usually the most significant part. In some IPOs, underwriter's compensation includes warrants which allow the underwriter to purchase the common stock of the issuer. Prior research, which is mainly on the US markets, provides different explanations for the use of warrants by IPO firms. For example, Barry, Muscarella and Vetsuypens (1991) argue that warrants are used by issuers to circumvent otherwise binding regulatory constraints on the amount of compensation that can be paid to underwriters. Dunbar (1995) shows that IPO firms use warrants in order to minimise their costs of going public. More recently, Garner and Marshall (2014) show that underwriter compensation contracts that include warrants in exchange for cash can serve as a certification mechanism for IPO firms. Interestingly, Garner and Marshall (2014) find that, when underwriters accept warrants when they could have received more cash, IPOs do not exhibit long-run underperformance in the aftermarket.

In this paper we study the use of warrants as part of the underwriter's compensation package for IPOs listed on the LSE. The UK institutional setting for underwriter compensation is very different from that of the US. While regulatory requirements in the US limit underwriter compensation to 'reasonable levels' and place constraints on the exercise price, the lock-in period and a minimum value for the warrants, the LSE carries none of these constraints. The LSE, therefore, offers a perfect laboratory in which to study the unfettered use of non-cash compensation of IPO underwriters. We focus on IPOs listed on the Alternative Investment

\footnotetext{
${ }^{1}$ The indirect costs of listing usually include underpricing, incremental organisational costs and managerial time and effort.
} 
Market (AIM) segment of the LSE for two reasons. First, AIM is driven by a flexible regulatory regime which is primarily principles based. Second, it is more common for AIM IPOs to use warrants as compared to their Main Market counterparts. During our sample period, nearly a third of the IPOs conducted on AIM issued warrants compared to only $4 \%$ of those listed on the LSE's Main Market

For a sample of AIM IPOs during 1995-2010, we find that, for warrant-issuing IPOs, the total underwriter compensation is made up of an average underwriting commission of $3.5 \%$ and an average value of warrants worth $2.4 \%$ of the gross proceeds. This total compensation of $5.9 \%$ is much lower than the 7\% (for large offerings) reported by Chen and Ritter (2000) and 13.9\% (for small IPOs) reported by Garner and Marshall (2014), for US IPOs. We then focus on a firm's decision to include warrants in the compensation provided to its underwriter. We investigate which types of firms are likely to issue warrants, whether reputable underwriters are more or less likely to accept warrants, and whether market conditions have an impact on the decision to issue warrants. We find that IPOs that are risky or cash constrained and those that hire high-quality underwriters are more likely to issue warrants. Further, warrants are more likely to be issued in volatile markets. Firms with large public floats are less likely to issue warrants.

Next, we investigate whether cost considerations are behind the use of warrants in UK IPOs. Using a 'what-if' analysis, our results suggest that most of the IPO firms make efficient decisions when choosing a compensation package for their underwriters. Those that choose to include warrants in the compensation package are able to minimise their total IPO costs (underpricing plus underwriter's compensation). More specifically, warrant-issuing IPO firms incur an average total cost of $29.1 \%$ of the gross proceeds. This cost would have been $33.8 \%$ had they not issued warrants. For IPOs that do not issue warrants, the actual total IPO cost is 17.7\%. This would have been $26.02 \%$ if these firms had issued warrants. These results 
provide support for Dunbar's (1995) 'cost minimisation' hypothesis and suggest that, in an environment such as the UK's where there are no regulations underlying the use of warrants and cash compensation, firms are still able to minimise their costs of going public.

The contribution of our paper is two-fold. First, to the best of our knowledge, ours is the first study to examine non-cash compensation of IPO underwriters in an environment with very light regulatory constraints on the issuance of warrants and no constrains on the payment of cash compensation to underwriters. Second, our study contributes to the ongoing debate on the dissatisfaction of companies and institutional investors with equity underwriting services in the UK; especially the increase in underwriter fees (Office of Fair Trading, 2011). ${ }^{2}$ While the Office of Fair Trading report focused on the underwriting fee in seasoned equity offerings, we provide direct evidence on the state of the IPO underwriting compensation in the UK.

The remainder of this paper is organised as follows. Section 2 discusses the literature on the use of warrants and our main research questions. In Section 3 we provide information on the AIM of the LSE. In Section 4 we describe our data. Section 5 explains our methodology, while Section 6 presents our results. Section 7 concludes.

\section{Related literature and research questions}

There are three main explanations that have been suggested in the literature to explain the issuance of warrants to underwriters as part of their compensation package: the circumvention hypothesis (Barry et al., 1991), the cost minimisation hypothesis (Dunbar, 1995) and the certification hypothesis (Ng and Smith, 1996). ${ }^{3}$ The circumvention hypothesis

\footnotetext{
${ }^{2}$ An investigation by the Office of Fair Trading, the UK's consumer and competition authority, into the underwriting fees of rights issues in the UK found that there had been a significant increase in the fees since the onset of the 2007-09 financial crisis. The average fee increased to 3\% in 2009 from $2 \%$ over 2003-2007. IPO underwriting fees were excluded from the investigation because they were considered a significantly different type of transaction involving different types of underwriting risk.

${ }^{3}$ The certification hypothesis of $\mathrm{Ng}$ and Smith (1996) relates to the presence of warrants in seasoned equity offerings but is also applicable to IPOs.
} 
argues that underwriters use warrants as a way to avoid the maximum compensation guidelines set by the Financial Industry Regulatory Authority (FINRA) (formerly the National Association of Securities Dealers - NASD). The circumvention hypothesis cannot be tested within the context of the LSE as there are no regulatory requirements that set maximum or minimum limits on underwriters' compensation in the UK. The cost minimisation hypothesis postulates that IPO firms minimise their costs of going public by issuing non-cash compensation to their underwriters. According to the certification hypothesis, underwriters include warrants as part of their compensation to certify that the issue is not overpriced.

The empirical literature that examines the use of warrants as part of the underwriters' compensation in firm commitment offerings is limited to the US. They also find, in line with the circumvention hypothesis, that investment banks do accept warrants so as to sidestep the FINRA's maximum compensation guidelines. The acceptance of warrants as part of the compensation package for underwriters in the US may, inadvertently, have been encouraged by the fact that the FINRA's pricing formula undervalues warrants when compared to the Black and Scholes and Constant Elasticity Variance (CEV) models. This is mainly due to the fact that the FINRA model does not take into account the volatility of the IPO shares (Garner and Marshall, 2014). This means that, whenever underwriters bring risky issues to the market, they include warrants in their compensation, instead of charging the issuers a high cash fee that would violate/exceed NASD guidelines. In addition, Barry et al. (1991) provide evidence that the total costs of going public are significantly higher for their warrant-issuing IPO sample than for their no-warrant sample, and these costs can be as much as $30 \%$ of the gross proceeds of the offering.

However, Dunbar (1995), who examines US firm commitment offerings during the period 1980-1983 and takes into account self-selection bias in his sample, finds that, for issuers who 
use warrants, the total costs of raising capital are lower than they would have been if warrants had not been used. Moreover, his results support the cost minimisation hypothesis, according to which issuers choose the type of contract that minimises their costs. Thus, underwriter warrants are chosen because they are considered a credible signal that the offering will not be overpriced (underwriter certification). This means that investors will require a smaller discount on the new issue, reducing the underpricing of the IPO and consequently the total costs of going public.

$\mathrm{Ng}$ and Smith (1996) use a two-stage logit model to account for self-selection. They find evidence that issuers select contracts that maximise their net proceeds. The total underwriter costs would have been much higher had the issuers not used warrants. That is to say, net proceeds would have been lower if warrants had not been used. Ng and Smith (1996) also find evidence in support of the certification hypothesis since less well-established underwriters, who lack reputational capital, certify offers by accepting warrants as part of their compensation. In this way, underwriters mitigate the information asymmetry problem regarding whether the issue might be overpriced, because their own compensation is tied to the aftermarket price performance. Moreover, consistent with previous studies, $\mathrm{Ng}$ and Smith (1996) show that warrants are mainly used by small and risky companies that have significant growth opportunities. Overall, the authors suggest that certification has a much greater effect on the decision to use warrants than circumvention.

Garner and Marshall (2014) study small US firm commitment offerings (gross proceeds of \$20 million or less) during the period 1993-2004 and find that the compensation structure of the IPO firms reveals information about their quality. When underwriters trade off warrants for cash compensation, or in other words when underwriters include warrants in their compensation packages instead of being paid more cash, then IPO companies avoid long-run underperformance. However, when underwriters maximise their cash compensation and on 
top of that also receive warrants, then IPO firms suffer higher underpricing and poorer longrun performance. In the last case, underwriters include warrants in their compensation packages in order to avoid regulatory constraints.

The focus of our paper is to seek answers to two important questions concerning the use of warrants as part of the compensation package to underwriters in an environment free from regulatory constraints. First, what are the determinants of the choice/decision of the IPO firm to partly compensate its underwriter with warrants? Second, does the inclusion of warrants in the compensation contract have any impact on the total costs of conducting an IPO or, in the spirit of Dunbar (1995), do IPO firms offer warrants to their underwriters in order to minimise their listing costs?

To answer the first question, we focus on firm-specific, underwriter and market-wide determinants of an IPO firm's decision to issue warrants to its underwriter. Prior evidence from the US shows that risky firms are more likely to use warrants (Barry et al., 1991) in order to provide extra compensation to their underwriters. We wish to test whether this is also the case in other markets such as the UK. Warrants can be seen as a form of deferred compensation to the underwriter. By using warrants, IPO firms can retain a larger part of their IPO proceeds. This option is particularly valuable for cash-constrained firms so we expect such IPO firms to be more likely to issue warrants to their underwriters. Warrants are also likely to be issued by firms whose initial owners are expected to retain large post-IPO stakes. If insiders retain a large stake in the IPO firm, they will consider mechanisms which insure them against the downside risk of the IPO failing to do well in the aftermarket. One such mechanism would be a warrant. As warrants require the underwriter to bear risk, they can be seen as a kind of insurance of the issuing firm.

Underwriters are repeat players in capital markets. While the need to maintain (or even build up) reputational capital provides the underwriter with an incentive to exert effort to conduct 
due diligence, warrants can also be seen as an extra disciplinary device that exposes the underwriter to the outcome of the IPO. A priori it is reasonable to predict that both low- and high-prestige underwriters would be offered warrants as a part of their compensation. However, Barry et al. (1991) and Garner and Marshall (2014) show that, for US IPOs, lowprestige underwriters are more likely to have warrants in their compensation packages. We seek to explore whether this is also the case in the UK.

For an IPO firm, the benefit of issuing warrants versus cash compensation may also vary with time and macro-economic conditions. For example, during periods of high market volatility, IPO firms are more likely to include warrants in their underwriters' compensation packages, as the insurance value of the warrants to the issuers will be high during these periods of uncertainty. During better market conditions, the insurance value of a warrant may be low, as firms may have easier and cheaper access to other sources of financing. This may result in IPO firms choosing a compensation package that reduces the total cost of the IPO, and thus they may not issue warrants. An alternative view could be that underwriters have the ability to time the issuance of warrants, and they ask for non-cash compensation when the market is doing well. The rationale is that, if the market is doing well, then it is likely that the company's stock price will rise in the aftermarket, the value of warrants will also rise, and consequently the compensation of the underwriter (including warrants) will increase.

Dunbar (1995) and $\mathrm{Ng}$ and Smith (1996) find that companies minimise their costs of going public by using non-cash compensation. ${ }^{4}$ The main source of this reduction in costs comes from reduced underpricing of the issue (Barry et al., 1991, Booth and Smith, 1986, Dunbar, 1995). If insiders can credibly send a signal to the market that they are not selling overpriced securities, then investors are likely to require a lower level of underpricing (Dunbar, 1995). One way to achieve that is to compensate the underwriters with warrants. Certification

\footnotetext{
${ }^{4} \mathrm{Ng}$ and Smith (1996) find that the net issue proceeds of seasoned equity offering firms would have been lower (or in other words costs would have been higher) had they not issued warrants.
} 
through warrants should be more valuable for smaller and riskier firms, which are characterised by greater informational asymmetries, because insiders may be better informed about the true value of the companies than outside investors. We wish to test whether the cost minimisation hypothesis also holds for the UK market.

\section{The Alternative Investment Market (AIM)}

The AIM, which was launched in June 1995, is the LSE's second-tier market and is designed mainly for smaller, growing companies that want to raise capital at a very early stage of their development. AIM is a prescribed, or in other words an exchange-regulated market as it is not supervised by the Financial Conduct Authority (FCA) of the UK but by the LSE. The most common method of conducting an IPO on AIM is through a placing in which shares are sold to qualified investors (informed investors) by the firm's underwriter via an admission document (rather than a prospectus). In the case of larger companies, if the goal is to raise a large amount of capital, a public offer is usually used. In the public offer, securities are issued to the public through a prospectus that must comply with the European Prospectus Directive requirements.

One plausible explanation for the success of exchange-regulated markets in attracting a high volume of IPOs is their light regulatory regime. AIM's regulatory system is tailored to the needs of growing and smaller companies, and its rules are less onerous than those of other markets that target larger and more established companies (Arcot et al., 2007, Nielsson, 2013). However, AIM companies are required to have a Nominated Advisor (Nomad) and a broker at all times (ongoing advisers), whereas firms listed in other markets do not.

The success of the AIM market is evident from the fact that, during the period from 1995 to $2009,44 \%$ of all IPOs conducted in the German, French, Italian and UK markets, and $77 \%$ of all IPOs listed on the exchange-regulated markets of the aforementioned countries, took place 
on AIM (Vismara et al., 2012). In addition, between 1995 and 2010, 1,811 companies were listed on AIM, raising a total of $£ 30.7$ billion. According to PricewaterhouseCoopers (2012b), London is the most international of all the capital markets around the world, with more than $21 \%$ of all companies listed maintaining operations outside the UK. The number of international firms joining AIM peaked in 2006, when 77 international issues took place, raising a total of $£ 2.9$ billion.

\subsection{The role of the broker (underwriter)}

On AIM a broker plays an integral part not only during the flotation process but also after the admission has taken place. According to Rule 35 of the AIM rules for companies (London Stock Exchange, 2010b) a firm listed on AIM should have a broker at all times. If the broker resigns or is dismissed, then the company should notify the market immediately (Rule 17). The purpose of Rule 35 is to ensure an orderly market for the securities of a company.

The roles of the broker and the Nomad are sometimes confused, especially when the same adviser is performing both roles. However, even when the Nomad and the broker are the same institution, the two roles are completely different. The Nomad is responsible for determining whether a company is suitable to be admitted to the AIM market and provides ongoing advice regarding the company's obligations and compliance with the AIM rules. On the other hand, the broker is responsible for arranging the fundraising ${ }^{5}$, maintaining a liquid aftermarket and generally ensuring that there is sufficient interest in the company's securities $^{6}$. When one adviser is simultaneously playing both roles (integrated house) then it should be an approved Nomad (approved by the LSE) and there should be a clear distinction between its responsibilities as a Nomad and its responsibilities as a broker (Chinese wall).

\footnotetext{
${ }^{5}$ The broker is responsible for organising the roadshows, procuring investors for the company's shares, building the book, collecting the funds from investors and allocating the shares. The broker also acts as a market maker for the company's shares.

${ }^{6}$ The broker advises the company on how to maintain good investor relations, provides information about relevant market and trading issues, and assists the firm with other corporate finance services and fundraising activities (i.e. rights issues, mergers).
} 
The broker plays a critical role in the IPO process on AIM since it is the party standing between the investors and the company, whereas the Nomad (regulator) is the party standing between the company and the AIM market.

The existing literature on AIM has paid no attention to the role of the broker, the focus always having been on the role of the Nomad (Gerakos et al., 2013, Mallin and Ow-Yong, 2011, Mallin and Ow-Yong, 2010, Mendoza, 2008). One of the most important roles of a broker is to act as an underwriter to the IPO.

\subsection{Underwriter's compensation structure}

The compensation an underwriter receives for advising a company seeking a listing on AIM consists of two main parts. The first is the commission, which is calculated as a percentage of the amount of money raised in the flotation and which is paid to the underwriter in return for procuring subscribers for the new shares and buyers for the selling/existing/secondary shares offered during the IPO. The second component is the retainer fee, which is paid annually to retain the adviser on an ongoing basis, post-listing.

In some cases warrants act as a third component of underwriters' compensation because some companies issue warrants to their underwriters in return for the services they provide. In these cases, the compensation of the underwriters is directly tied up with the aftermarket performance of the stock price. If the offering is overpriced and the stock price drops in the aftermarket, then the value of the warrants decreases and the total compensation of the advisers also decreases. If the offering is underpriced and the stock price increases in the aftermarket, the value of the warrants increases and the total underwriter compensation (including warrants) increases.

For AIM, there is no regulation setting a maximum or minimum for underwriters' compensation (see Appendix Table A1). The amount of commission and annual retainer fees 
the underwriter is paid depends on its initial agreement with the issuer. This applies to both underwritten and non-underwritten offerings. In contrast to the LSE, in the US stock exchanges, underwriter compensation is subject to the FINRA $^{7}$ rules, according to which underwriting expenses are expected to be 'fair and reasonable'. More specifically, the maximum compensation guidelines (including warrants) are different for firm commitment and best-effort offerings (Notice 92 - 53, FINRA Manual). The maximum amount of compensation that can be paid in the US varies directly with the risk assumed by the underwriter (firm commitment or best-effort offerings) and inversely with the gross proceeds (FINRA Rule 5110). For instance, if the money raised from the IPO is \$25 million then the maximum proposed compensation for the underwriter is $7.29 \%$ or $6.68 \%$ of the gross proceeds, for firm commitment and best-effort offerings respectively (Notice $92-53$, FINRA Manual). ${ }^{8}$

\section{Data}

Our data include all non-financial IPOs listed on AIM over the period from June 1995 to December 2010. After excluding all financial industry listings, the initial sample consists of 1,259 firms. 902 of these offerings are not underwritten whereas 10 are partly underwritten (less than $50 \%$ of the shares sold are underwritten). 6 IPOs were listed on other stock exchanges before being listed on AIM, and are therefore excluded from our sample. ${ }^{9}$ The remaining sample consists of 341 underwritten IPOs, which is approximately $27 \%$ of all AIM listings. This is in stark contrast to the US market, in which $65.5 \%$ of the IPOs are underwritten (Ritter, 1987). We further exclude 13 unit IPOs, 4 IPOs due to the unavailability of admission documents, and 8 IPOs that issued warrants to other advisers (i.e. Nomads). This leaves us with a final sample of 316 underwritten IPOs.

\footnotetext{
${ }^{7}$ FINRA is the largest independent securities regulator in the US market. 8 For a detailed discussion of the differences between US and European IPO markets see Ritter (2003).

${ }^{9}$ For example, Petmin Limited conducted an IPO on 20 December 2006, but had already been listed on the Johannesburg Stock Exchange in 1986. Similarly, Tricorn Group plc conducted an IPO on 5 December 2001, but was previously listed on OFEX (renamed the PLUS Market).
} 
The stock price data are extracted from DataStream, Thomson One Banker and Bloomberg. The data regarding underwriter's compensation (commission and warrant characteristics such as shares underlying the warrants, exercise price and time to expiration), issue price, gross proceeds, firm value at offer price, date of incorporation, and cash available in the year prior to the IPO are collected from the admission documents. Information on the credit score of the underwriter is collected from the FAME database.

\section{Methodology}

The issuance of warrants may be related to the underpricing and total underwriter compensation costs incurred by companies during IPOs. The decision to issue warrants may be a non-random one because companies may choose the contract that is more favourable for them (Li and Prabhala, 2007). This is likely to be true as companies rarely make decisions randomly (Hamilton and Nickerson, 2003). As a result, if the IPOs that issue warrants are not a random subset of the whole population then OLS regressions will not yield consistent estimates. The two-stage Heckman (1979) selection model can control for this endogeneity problem (selection bias).

We make use of the endogenous switching model, which is an extension of the baseline Heckman self-selection model. In the first stage, this model (the selection model) consists of a binary choice equation which captures the decision to issue warrants and is as follows:

$$
I_{i}^{*}=Z_{i} \gamma+\varepsilon_{i}
$$

Vector $Z_{i}$ includes all observable independent variables that may influence the decision to issue warrants. Some of these variables may also affect the underpricing and total underwriter compensation. Vector $\gamma$ includes all parameters that must be estimated and $\varepsilon_{i}$ is the error 
term. We use a probit model to estimate the selection model, in which the dependent variable $I_{i}^{*}$ is equal to one if the firm issues warrants and zero otherwise:

$$
I_{i}=1 \text { iff } I_{i}^{*}>0 \text {, and } I_{i}=0 \text { iff } I_{i}^{*} \leq 0
$$

By using the estimated value of $Z_{i} \hat{\gamma}$ we compute the inverse Mills ratio (IMR), which is different for IPOs that issue warrants and those that do not. The IMR is then included in the second stage of the Heckman model, in which we have two regression equations for the variable of interest conditional on the choice made in the first stage. The second-stage equations are as follows:

$$
\begin{aligned}
& y_{1 i}=X_{i} \beta_{1}+u_{1 i} \\
& y_{2 i}=X_{i} \theta_{2}+u_{2 i}
\end{aligned}
$$

Equation (3) is the underpricing equation for the IPOs that issue warrants to the underwriters, and equation (4) is the underpricing equation for those that do not. We only observe either $y_{1 i}$ or $y_{2 i}$, for each IPO, based on the outcome of $I_{i}$ :

$$
y_{i}=y_{1 i} \text { iff } I_{i}=1 \text {, and } y_{i}=y_{2 i} \text { iff } I_{i}=0
$$

$y_{i}$ includes the underpricing and $X_{i}$ includes the independent variables that affect the underpricing when the IPO firms issue warrants or when they do not. We use the same methodology in order to examine the relation between the use of warrants and total underwriter compensation, by replacing the two underpricing equations with two total 
underwriter compensation equations. In this case, $x_{\tilde{i}}$ will consist of variables that affect the total underwriter compensation when warrants are or are not used.

By using a self-selection regression model, we attempt to address the endogeneity problem, as we allow the error in equation (1) to be correlated with the errors in equations (3) and (4), so that unobserved or missing variables in the binary outcome equation (1) can also have an effect on the underpricing. Parameters $\beta_{1}$ and $\theta_{2}$ cannot be estimated directly using OLS because this will generate inconsistent estimates since the expectation of $y_{1 i}$ does not have a zero mean $\left(\mathrm{u}_{1}\right.$ and $\varepsilon$ may be correlated). For this reason, in the second stage, we estimate equations (3) and (4) by OLS, including one additional regressor to adjust for the potential non-zero expectation of the errors. This regressor is the IMR, which allows equations (3) and (4) to be estimated consistently using OLS (Lee, 1978, Heckman, 1979). The IMR is defined as follows:

$I M R_{1}=-\frac{\varphi\left(z_{i} \gamma\right)}{\Phi\left(z_{i} \gamma\right)}$ for IPOs that issue warrants.

$I M R_{2}=\frac{\varphi\left(z_{i} y\right)}{1-\Phi\left(z_{i} y\right)}$ for IPOs that do not issue warrants

where $\varphi$ is the standard normal density function and $\Phi$ is the standard normal cumulative distribution function. If at least one of the IMRs in equations (3) and (4) is statistically significant then this will imply that there is self-selection and we will have to use the twostage Heckman model. If none of the IMRs is statistically significant then the OLS estimates will not be affected by selection bias (Golubov et al., 2012, p. 291).

The independent variables included in vectors $Z_{i}$ and $X_{i}$ can also be identical. In other words it is not necessary to apply any exclusion restrictions in the second-stage regressions because they are not critical in the Heckman selection model, as this model is identified by the 
nonlinearity of the IMRs. Therefore, the second-stage regressions are still valid even without any exclusion restrictions (Golubov et al., 2012, p. 304). Ng and Smith (1996, pp. 372, 373) do not apply any exclusion restrictions in their analysis on the issuing of warrants to underwriters on seasoned equity offerings. However, Li and Prabhala (2007) suggest that it is advisable to have a variable that is included amongst other variables in the first-stage equation, but not in the outcome equations (second stage). The only role that this variable will play is that it affects the choice of the type of compensation contract (cash only vs. cash plus warrants). We use the ratio of cash and cash equivalent to total gross proceeds as our exclusion variable. Our reasoning is that the cash position of the IPO firm at the time of listing may have a bearing on the use of warrants, but not on the actual underpricing and the total costs (underpricing plus underwriting fees) of listing. This could be particularly true for firms that have immediate cash needs. As warrants represent a form of deferred compensation of the underwriter, by issuing warrants, IPO firms are able to retain a larger part of the cash raised in the offering.

Following prior literature, we include four variables as proxies for the ex-ante uncertainty of an IPO firm: the age of the firm, the standard deviation of returns for the first 20 trading days following the official listing (Ritter, 1984, Barry et al., 1991), the inverse of the offer price and the percentage of gross proceeds raised from selling existing shares in the IPO (Dunbar, 1995). Cash/GP is the cash and cash equivalents available in the year prior to the IPO divided by the gross proceeds. We control for the size of the company as previous research (Barry et al. 1991, Dunbar 1995 and $\mathrm{Ng}$ and Smith 1996) documents that smaller firms issue compensation warrants to their underwriters. We include the variable Firm size, which measures the value of the firm at the offer price. In addition, we include the variable Public float in our two-stage model, as Habib and Ljungqvist (2001) and Loughran and Ritter (2002) report that the gross proceeds and public float can have an effect on the underpricing of IPOs. 
It is a common practice to use the Carter and Manaster (1990) ranking to capture the underwriter's reputation in US IPOs. However such measure of underwriter reputation is not suitable for the European market (Migliorati and Vismara 2014). We use Migliorati and Vismara (2014) ranking of AIM underwriters which is based on the market share of the underwriter using gross proceeds. ${ }^{10}$ In addition to this measure, we also include a reputational measure based on the underwriter's credit score (Espenlaub et al. 2012). To control for the market environment around the time of the IPO, we use the volatility of the FTSE AIM All Share Index during the two months prior to the IPO. ${ }^{11}$ To take into account the hotness of the IPO cycles, we include a hot-issue market variable. This variable captures the average underpricing in the market in the last three months before the IPO.

We employ Cox's CEV model to value the warrants. We follow Dunbar's (1995) approach and use the first day's closing price of the underlying stock rather than its offer price. This can be justified by the fact that underwriters may have inside information about the company's value when the offer price is decided (Barry et al., 1991) as they are responsible for conducting the bookbuilding, in which they contact institutional investors, obtain bids for the company's shares and consequently determine the issue price (Burton et al., 2006, Jenkinson and Jones, 2004, London Stock Exchange, 2007b).

Barry et al. (1991) calculate the average standard deviation for all the stocks that exist in the CRSP database for a time period of 126 trading days prior to the offer. This is equivalent to forming a CRSP equity index as they use all available stocks in the CRSP database. According to the AIM admission timetable (London Stock Exchange, 2009), the company appoints its advisers (broker and Nomad) and agrees the timetable for listing, 12 to 24 weeks (approximately 120 working days) before admission. This implies that the advisers, in

\footnotetext{
${ }^{10}$ We are grateful to Silvio Vismara for providing us with the AIM underwriter rankings.

${ }^{11} \mathrm{We}$ also measure the volatility of the market over other periods such as three months. Our results remain unchanged.
} 
collaboration with the management of the firm, decide when the listing will take place, 12 to 24 weeks before the actual IPO date. Thus, we compute the average standard deviation of the FTSE AIM All Share Index across the 126 days before the offering. Barry et al. (1991) also use sector volatilities, and their results are qualitatively the same. We were unable to use AIM sector indices to calculate the volatility since some of them did not exist during the period of study (i.e. automobiles and parts, and food and beverages were introduced at the end of 2000).

However, Barry et al.'s (1991) and our measure of volatility has one disadvantage. Seasoned companies are quite different and inherently less volatile than newly listed ones (Barry et al., 1991, Boehme and Çolak, 2012, Clarkson and Thompson, 1990, Ibbotson, 1975). Thus, we use two alternative measures of volatility, based on 20 and 126 days of company-specific returns in the aftermarket. We use the Bank of England base rate in the month of the offering as a measure of the risk-free rate.

\section{Results}

\subsection{Descriptive statistics - univariate analysis}

Table 1 reports the descriptive statistics of the warrant and non-warrant subsamples and the total sample of underwritten offerings for the period from 1995 to 2010. In our sample, 93 out of the 316 underwritten offerings issue warrants to their underwriters and 223 do not. Thus, $29.4 \%$ of the underwritten IPOs on AIM grant warrants to their underwriters. This figure is higher than the $17.4 \%$ reported by Barry et al. (1991), but lower than the $37.9 \%$ reported by Dunbar (1995), and 34.5\% (for small non-unit IPOs) reported by Garner and Marshall (2014) for US IPOs.

The figures in the table show that the IPOs that issue warrants to their underwriters are more heavily underpriced than their non-warrant counterparts (23.2\% vs. $14.3 \%)$. Warrant issuers 
usually have a lower issue price (£0.83) than non-issuers (£1.17). According to Fang (2005), Klein and Leffler (1981), Shapiro (1983) and Allen (1984) higher prices can be an indicator of superior quality. Furthermore, firms in the warrant IPO group have a lower public float (33\%) and a higher standard deviation of returns in the aftermarket $(3.1 \%)$ than those in the no-warrant group, which have a public float of $38.6 \%$ and a standard deviation of returns of 2.4\%. Warrant issuing firms are younger at the time of listing, have lower gross and secondary proceeds and are smaller (firm size) than their no-warrant counterparts. ${ }^{12}$ Warrantissuing firms have much smaller cash balances than their no-warrant counterparts in the year prior to the IPO. These findings are consistent with Barry et al. (1991), Dunbar (1995), Jain and Kini (1999) and Garner and Marshall (2014), who report that issuers who grant warrants as part of their compensation package for the underwriters are on average smaller, have a higher aftermarket standard deviation, offer their shares at lower issue prices and, in general, are riskier and more difficult to market.

The figures reported in Table 1 also reveal that IPOs that issue warrants pay a higher commission $(3.5 \%$ vs. $3.3 \%)$ to their underwriters than those in the no-warrant group. The differences in both the means and the medians are statistically significant at the $10 \%$ level. These findings are not consistent with those of Barry et al. (1991), who report that underwriter cash compensation is significantly higher for the warrant group of companies. Our results also show that, when warrants are included in the compensation package, then the total underwriter compensation (commission plus value of warrants) is significantly higher for the warrant IPO group (5.9\%) than the no-warrant group (3.3\%). The differences in both the means and the medians are statistically significant at the $1 \%$ level. This finding is consistent with Dunbar (1995), who also reports that the mean underwriter compensation is significantly higher for the companies that issue warrants to their investment banks.

\footnotetext{
${ }^{12}$ Our sample of warrant issuers raise higher gross proceeds and have a higher firm value at offer price than the samples of Barry et al. (1991) and Dunbar (1995), adjusted for inflation and exchange rates. Comparative figures are available from the authors upon request.
} 
For our two different measures of underwriter reputation, we find that firms in the warrant IPO group are more likely to be underwritten by a more reputable underwriter than those in the no-warrant group. This is in stark contrast to the US evidence, which shows that firms that issue warrants to their underwriters are underwritten by less reputable investment banks (Barry et al., 1991, Dunbar, 1995, Bae and Jo, 2007, Jain and Kini, 1999, Garner and Marshall, 2014). This suggests that high-quality underwriters, who have a comparative advantage at due diligence and stronger reputations, take on riskier IPOs that low-reputation underwriters may find difficult to market.

\section{[Insert Table 1 here]}

To further explore the relationship between underwriter reputation and the usage of warrants in the compensation contract, we rank our underwriters based on the gross proceeds raised from the IPOs they underwrite. Table 2 provides descriptive statistics for the bottom and top $10 \%$ of underwriters. About $60 \%$ of all warrants (56 out of 93) are issued by companies that are underwritten by the top $10 \%$ of underwriters, whereas the equivalent percentage for companies advised by the bottom $10 \%$ of underwriters is only about $3 \%$ ( 3 out of 93 ). For instance, Collins Stewart (the most reputable underwriter based on market share) advised $11 \%$ of all IPOs (33 IPOs) and raised $19 \%$ of the total gross proceeds (£1136.78 mil.) raised by all the IPOs in the sample. Out of the 33 IPOs underwritten by Collins Stewart, 17 of them (or 52\%) issued warrants. Thus, in total, Collins Stewart alone underwrote 18\% (17 out of 93) of all the IPOs that issued warrants. A possible explanation for the very limited involvement of the less reputable underwriters in the underwriting of riskier IPOs that issue warrants is that these underwriters may have neither a broad distributional network of institutional investors to whom they can sell the IPO shares, nor the capital to absorb any unsold shares from these risky IPOs.

\section{[Insert Table 2 here]}




\subsection{Warrant characteristics}

Table 3 reports the characteristics of the 93 warrants issued to the underwriters as part of their compensation package. Panel A of the table shows that the average size and value of warrants (expressed as a percentage of the number of shares issued and the gross proceeds) are $6.5 \%$ and $2.4 \%$ respectively. The warrants have a maximum (minimum) size and value of $133.2 \%$ and $25.1 \%(0.2 \%$ and $0 \%)$ respectively. For the valuation of the warrants, we measure the volatility of the FTSE AIM All Share Index over the 126 days before the offering. The average value of the warrants is $2.4 \%$ of the gross proceeds and enhances the underwriters' underwriting compensation package by about $69 \%$ (not reported in the table). Barry et al. (1991) report an average size and value of warrants of $7.9 \%$ and $3.92 \%$ respectively, for issues that raised $\$ 10$ million or more in the IPO. $\mathrm{Ng}$ and Smith (1996) find a warrant value of $5.67 \%$ for seasoned equity offerings. The average ratio of exercise price to offer price is almost equal to 1 and the ratio has a minimum and maximum value of 0.55 and 1.62 respectively. The warrants have an average life span of 3.8 years. This is shorter than the 4.9 years reported by Barry et al. (1991). In addition, our data show a maximum expiry period of 21 years, whereas, in the US, according to FINRA Rule 5110, the expiry period is restricted to 5 years (Barry et al., 1991, Ng and Smith, 1996).

Panel B of the table reveals that almost $72 \%$ (67 out of 93) of the warrants are granted to underwriters without any lock-in agreements. These warrants can be exercised from the first day of trading. However, this is not the case in the US as the FINRA Rule 5110 imposes a minimum lock-in period of 180 days. The figures in Panel C show that for the 26 IPOs that issued warrants with a lock-in period, the average lock-in period is 0.87 years. The shortest lock-in expiry is 3 months after the IPO whereas the maximum lock-in period is 2.5 years (as shown in Panel A). Panel D shows that 80 IPOs offered warrants to underwriters at an exercise price equal to the offer price. The finding that, on average, the exercise price of the 
warrants is almost equal to the offer price is in contrast to Barry et al. (1991), who find a ratio of 1.205 , with $96 \%$ of the warrants in their sample having an exercise price equal to or greater than $120 \%$ of the offer price. Garner and Marshall (2014) also report a figure of 1.20. The US findings can, to a large extent, be explained by US state blue sky laws on securities. Panel E shows that only 3 IPOs (about 3\%) issued warrants at an exercise price below the issue price (at an average of $20 \%$ below the issue price). Thus, the warrants of these 3 IPOs were already in the money prior to listing. This was not permitted in the US prior to 2004 (NASD Rule 2710). Finally Panel F of Table 3 shows that only 10 warrants (approximately $11 \%$ ) have an exercise price that is almost $25 \%$ higher than the offer price.

To summarise, in an environment with minimum regulatory constraints underlying non-cash compensation, as is the case with AIM, warrants are usually issued at an exercise price which is equal to the offer price, about a quarter have lock-in agreements and the expiry of the warrant can be as short as an year and as long as 21 years.

\section{[Insert Table 3 here]}

\subsection{Multivariate analysis of warrants issuance}

Table 4 reports the results of the reduced-form probit model in which the dependent variable is a dummy that takes the value of one when warrants are used and zero otherwise. Two different probit models are presented, differing in the measurement of underwriter's reputation. Model 1 includes a reputational measure based on the Migliorati and Vismara (2014) underwriter ranking using gross proceeds while Model 2 uses credit score of the underwriter as a reputational measure. From the table it is evident that riskier firms are more likely to issue warrants to their underwriters. Firms that have a higher aftermarket standard deviation of returns or a higher inverse offer price ratio have a higher likelihood of issuing warrants. The results further show that the probability of using warrants is inversely related to 
the free float of the IPO. If, as a result of the IPO, insider ownership of the issuing firm will be low, then there is a lower likelihood that the IPO firm will issue warrants. This finding is not consistent with that reported by Dunbar (1995). In addition, the cash and cash equivalents (as a percentage of gross proceeds) that the companies have at their disposal the year prior to the IPO have a negative effect on the probability they will issue warrants. Thus, companies that are cash constrained appear to be more inclined to issue warrants.

Irrespective of the definition we use, underwriter reputation has a positive and statistically significant effect on the probability of warrants being issued. Thus, the probability of issuing warrants is higher for companies that are underwritten by reputable underwriters. This is in contrast to the finding of Dunbar (1995), who reports that the probability of issuing warrants is higher for firms that are underwritten by less reputable underwriters. One possible explanation for our result is that less reputable underwriters will, on average, avoid bringing riskier IPOs to the market because they may not be able to procure enough investors for the company's shares and they may be undercapitalised, meaning that they do not want to take on the risk of subscribing to unsold shares. On the other hand, more reputable underwriters may bring riskier companies, that issue warrants, to the market (as well as less risky companies) because they have a comparative advantage in terms of due diligence and have a wider network of institutional investors (Fang, 2005) to whom they can sell the shares. Hence, they are willing to take on more risky offerings. During volatile markets and hot issue periods, the likelihood of IPO firms issuing warrants is high.

Both models 1 and 2 have strong predictive power with almost $75 \%$ correct predictions. The predictive power of our models compares quite favourably to the naïve model. The naïve model consists of predicting that all IPO firms choose the compensation contract with the highest frequency in our sample. This is the non-warrant compensation contract. In our sample we have 223 observations without warrants and 93 observations with warrants. 
Hence, the naïve model, by predicting all outcomes as non-warrant contracts, is correct in only 223 out of 316 cases, or $70 \%$ of the cases.

\section{[Insert Table 4 here]}

The results obtained from the first-stage (reduced-form) probit regression are used to construct the IMR. In the second-stage regression, the variables of underpricing and total underwriter compensation are regressed on the IMR and on the independent variables, separately for the two IPO groups, those with warrants and those without. Table 5 reports the results of the second-stage regressions based on model 1 of Table 4.

The results reported in Table 5 show that two of the IMR coefficients are statistically significant, which suggests that there is selectivity bias, and without them OLS regressions would yield biased and inconsistent estimates. For the companies in the warrant group, underpricing is significantly and negatively related to the age of the firm and firm size and positively related to one over the offer price. As expected, these results show that investors require lower underpricing when the firm has low risk. Underpricing is also higher during volatile markets and also during hot-issue markets. For the same group of companies (warrant group), the total underwriter compensation is significantly and positively related to the riskiness of the firm as measured by the standard deviation of returns and one over the offer price. Older firms pay lower underwriter compensation. In volatile markets, the underwriter compensation is lower whereas in hot issue markets, it is higher.

For the non-warrant IPO group, the determinants of underpricing are similar to those of the warrant issuing group. Riskier non-warrant firms have higher underpricing. The results also show that for this group, underpricing is negatively related to underwriter reputation and the volatility of the market. In hot issue markets, these firms have higher underpricing. For the same group of companies, total underwriter compensation increases with the riskiness of 
these firms. IPOs underwritten by reputable underwriters have lower total compensation. Surprisingly the volatility of the market is negatively related to underwriter compensation. Hot issue markets are associated with higher underwriter compensation. Overall, the results for the non-warrant group show that the higher is the riskiness of the firm, the higher will be the underpricing and the total underwriter compensation.

\section{[Insert Table 5 here]}

The coefficients in Table 5 are used to estimate what the underpricing and total underwriter compensation would have been had the alternative contract (warrants vs. no warrants) been used. We multiply the coefficient estimates from the second-stage regressions (Table 5) by the independent variables. Then, we compare these values with the actual underpricing and total underwriter compensation, and report them in Table 6.

Table 6 shows that, for IPOs that issue warrants to their underwriters, the mean actual underpricing is $23.2 \%$ but would have been $29.69 \%$ if warrants had not been used. This means that these companies would have experienced much higher underpricing had warrants not been issued. This finding is consistent with that of Dunbar (1995), who reports a mean underpricing of $23.3 \%$ for companies that issue warrants, and a figure of $36.4 \%$ had warrants not been used.

For the same group of companies (the warrant IPO group), the total underwriter compensation is $5.9 \%$ but would have been $4.11 \%$ if warrants had not been used. This suggests that if these companies had not issued compensation warrants they would have paid a lower fee to their underwriters, but this would have occurred at the expense of higher underpricing. Dunbar (1995) finds qualitatively similar results.

Adding up the two aforementioned costs (underpricing and total underwriter compensation) we observe that IPOs that issue warrants incur a total cost of $29.1 \%$. This figure would have 
been much higher, $33.80 \%$, had the firms not issued warrants. Therefore, companies are able to minimise their total costs of going public and reduce them by 4.70 percentage points by issuing warrants to their underwriters (cost minimisation). This is due to the fact that warrants are a credible signal that the issuers are not selling overpriced securities. As a result, investors require less discounting in the offer price, reducing the underpricing cost for the IPO firm (23.2\% vs. $29.69 \%)$.

For the no-warrant group, the mean actual underpricing is $14.3 \%$ but it would have been $21.1 \%$ had they issued warrants. This result is different from that of Dunbar (1995), who finds that, for companies that do not issue warrants, the underpricing would have been unaffected by their use. As for the total underwriter compensation, our results show that companies pay compensation of $3.3 \%$ and would have paid $4.92 \%$ had they issued warrants. This finding is consistent with that of Dunbar (1995). If we add up the two aforementioned costs, then companies that do not issue warrants incur total costs of $17.6 \%$ and this figure would have been $26.02 \%$ had they chosen to issue warrants.

Overall, it is evident from our results that companies that make use of non-cash compensation minimise their costs of going public, just as their counterparts in the US do. Dunbar (1995) suggests that the FINRA (formerly NASD) should relax the warrant regulations, as they are unnecessarily restrictive. More specifically, according to Dunbar (1995), the 10\% maximum limit underlying the amount of warrants that can be offered to the underwriters as part of their compensation restricts their ability to certify the offering price. In 2004, the NASD actually relaxed its non-cash compensation regulations and abolished the aforementioned requirement. Our findings further suggest that, even in an environment where there are almost no regulations underlying non-cash compensation, IPO firms are still able to choose a contract that minimises their total costs of going public.

\section{[Insert Table 6 here]}




\section{Conclusion}

We examine the use of warrants as part of the underwriter's compensation in underwritten offerings on the AIM market of the LSE. The uniqueness of the LSE is that it presents an environment where there are no regulatory constraints relating to an upper ceiling for the cash component of the underwriters' compensation package or the warrants issued as part of the compensation. The LSE therefore offers a perfect opportunity to study the type of firms that choose to include warrants and to test the efficacy of some of the explanations that have been suggested for the use of warrants in others markets such as the US.

Our findings show that companies that issue warrants are riskier and are more likely to be underwritten by reputable underwriters. Cash-constrained firms are also more likely to include warrants in their compensation of their underwriters. IPOs that come to the market when the market volatility is high are more likely to issue warrants. Similarly warrant issuance is more likely in hot issue markets.

We further find that UK IPO firms make rational decisions when choosing a compensation package for their underwriters. For companies that issue warrants, the total costs of the IPO (underpricing plus the total underwriter compensation) are much lower (about 4.7 percentage points) than the 'counterfactual' costs they would have incurred had they not used warrants. Similarly, for firms that do not issue warrants, it is much cheaper not to do so. Had they issued warrants, their total costs would have been almost 8 percentage points higher. These results support the cost minimisation explanation for the use of warrants.

Overall, our results suggest that, in an environment in which there are no regulations related to non-cash compensation, IPO firms are still able to minimise their costs of going public through the use of warrants. In a broader context, our results show that self-disciplined markets such as the LSE's AIM work equally well as their regulated US counterparts. 


\section{Aknowlegments}

The authors thank an anonymous referee, Susanne Espenlaub, Ranko Jelic, Abdulkadir Mohamed and Jeffry Netter (the editor) for their constructive comments. We also thank the seminar participants at the U.K Financial Conduct Authority (formerly known as the Financial Services Authority) and the University of Birmingham for helpful comments. Any errors are our own. This research did not receive any specific grant from funding agencies in the public, commercial, or not-for-profit sectors.

\section{References}

Allen, F., 1984. Reputation and product quality. Rand J Econ. 15, 311-327.

Arcot, S., Black, J., Owen, G., 2007. From local to global: the rise of AIM as a stock market for growing companies. Prepared by The London School of Economics as commissioned by the London Stock Exchange.

Bae, S., Jo, H., 2007. Underwriter warrants, underwriter reputation, and growth signalling. Rev. Quant. Finan. Acc. 29, 129-154.

Barry, C. B., Muscarella, C. J., Vetsuypens, M. R., 1991. Underwriter warrants, underwriter compensation, and the costs of going public. J. Finan. Econ. 29, 113-135.

Boehme, R., Çolak, G., 2012. Primary market characteristics and secondary market frictions of stocks. J. Finan. Markets, 15, 286-327.

Booth, J. R., Smith, R. L., 1986. Capital raising, underwriting and the certification hypothesis. J. Finan. Econ. 15, 261-281.

Burton, B., Helliar, C., Power, D., 2006. Practitioners' Perspectives on the IPO Process and the Perils of Flotation. Eur. J. Finan. 12, 671-692.

Carter, R., Manaster, S., 1990. Initial Public Offerings and Underwriter Reputation. J. Finan. 45, 1045-1067.

Chen, H. C., Ritter, J. R., 2000. The Seven Percent Solution. J. Finan. 55, 1105-1131.

Clarkson, P. M., Thompson, R., 1990. Empirical estimates of beta when investors face estimation risk. J. Finan. 45, 431-453.

Dunbar, C. G., 1995. The use of warrants as underwriter compensation in initial public offerings. J. Finan. Econ. 38, 59-78.

Espenlaub, S., Khurshed, A., Mohamed, A., 2012. IPO survival in a reputational market. J. Bus. Finan Acc. 39, 427-463.

Fang, L. H., 2005. Investment Bank Reputation and the Price and Quality of Underwriting Services. J. Finan. 60, 2729-2761.

Garner, J. L., Marshall, B. B., 2014. Underwriter Compensation Structure: Can It Really Bond Underwriters? Finan. Rev. 49, 21-48.

Gerakos, J. J., Lang, M. H., Maffett, M. G., 2013. Post-listing performance and private sector regulation: The experience of London's Alternative Investment Market. J. Accting and Eco. $56,189-215$.

Golubov, A., Petmezas, D., Travlos, N. G., 2012. When It Pays to Pay Your Investment Banker: New Evidence on the Role of Financial Advisors in M\&As. The J. Finan. 67, 271311. 
Habib, M. A., Ljungqvist, A. P., 2001. Underpricing and entrepreneurial wealth losses in IPOs: theory and evidence. Rev. Finan. Stud. 14, 433-458.

Hamilton, B. H., Nickelson, J. A., 2003. Correcting for Endogeneity in Strategic Management Research. Strateg. Organ. 1, 51-78.

Heckman, J. J., 1979. Sample selection bias as a specification error. Econometrica 47, 153161.

Ibbotson, R. G., 1975. Price performance of common stock new issues. J. Finan. Econ. 2, 235-272.

Institutional Investor Committee, 2011. Best Practice Guidance for Issuers when Raising Equity Capital.

Jain, B. A., Kini, O., 1999. On investment banker monitoring in the new issues market. J. Bank. Finan. 23, 49-84.

Jenkinson, T., Jones, H., 2004. Bids and Allocations in European IPO Bookbuilding. J. Finan. 59, 2309-2338.

Kaserer, C., Schiereck, D., 2008. Primary Market Activity and the Cost of Going and Being Public. Deutsche Börse Group

Klein, B., Leffler, K. B., 1981. The role of market forces in assuring contractual performance. J. Polit. Econ. 89, 615-641.

Lee, L.-F., 1978. Unionism and Wage Rates: A Simultaneous Equations Model with Qualitative and Limited Dependent Variables. Intern. Econ. Rev. 19, 415-433.

Li, K., Prabhala, N. R., 2007. Self-Selection Models in Corporate Finance. Handb. Corp. Finan.: Empir. Corp. Finan., 47-62.

London Stock Exchange, 2010a. A guide to listing on the London Stock Exchange.

London Stock Exchange, 2010b. AIM Rules for Companies.

London Stock Exchange, 2009. AIM admission timetable - an example.

London Stock Exchange, 2007a. AIM Rules for Nominated Advisers.

London Stock Exchange, 2007b. Joining AIM: A Professional Handbook.

Loughran, T., Ritter, J. R., 2002. Why Don't Issuers Get Upset About Leaving Money on the Table in IPOs? Rev. Finan. Stud. 15, 413-444.

Mallin, C., Ow-Yong, K., 2011. Factors influencing corporate governance disclosures: evidence from Alternative Investment Market (AIM) companies in the UK. Eur. J. Finan. 18, 515-533.

Mallin, C., Ow-Yong, K., 2010. The UK Alternative Investment Market - Ethical Dimensions. J. Bus. Ethics 95, 223-239.

Mendoza, J. M., 2008. Securities Regulation in Low-tier Listing Venues: The rise of the Alternative Investment Market. Fordham J. Corp. Finan. Law 13, 257 - 328.

Migliorati, K., Vismara, S., 2014. Ranking Underwriters of European IPOs, European Financial Management 20, 891-925.

National Association of Securities Dealers, 2004. Amendments to the Corporate Financing Rule.

Ng, C. K., Smith, R. L., 1996. Determinants of Contract Choice: The Use of Warrants to Compensate Underwriters of Seasoned Equity Issues. J. Finan. 51, 363-380. 
Nielsson, U., 2013. Do less regulated markets attract lower quality firms? Evidence from the London AIM market. J. Finan. Intermediation 22, 335-352.

Ritter, J. R., 1984. The 'hot issue' market of 1980. J. Bus. 57, 215-240.

Ritter, J. R., 1987. The costs of going public. J. Finan. Econ. 19, 269-281.

Ritter, J.R., 2003. Differences between European and American IPO markets. Eur. Financ. Manag. 9 (4), 421-434.

Shapiro, C., 1983. Premiums for high quality products as returns to reputations. Quart. J. Econ. 98, 659-679.

Vismara, S., Paleari, S., Ritter, J. R., 2012. Europe's Second Markets for Small Companies. Eur. Financ. Manag. 18, 352-388 


\section{Table 1}

\section{Comparison between warrant and no-warrant IPO groups}

Underpricing is the first-day return and is calculated as (closing price - issue price)/issue price. Public Float is the shares sold in the IPO divided by outstanding shares. Standard Deviation is the standard deviation of returns for 20 days in the aftermarket. Age is the number of years from incorporation to flotation. Gross Proceeds is the money raised from the flotation, measured as the offer price times the total number of shares offered. Secondary Proceeds is the percentage of gross proceeds raised from the selling of existing shares in the IPO and is calculated as gross proceeds from existing shares/total gross proceeds. Firm Size is the value of the firm at the offer price. Cash relates to the cash position of an IPO firm in the year prior to the IPO. Commission is the money paid to the underwriters (as a \% of gross proceeds). The Value of Warrants is obtained from the CEV model and is measured as a percentage of gross proceeds. Total Underwriter Compensation is the summation of the commission and the value of warrants. Value of Warrants/Commission is the Value of Warrants divided by the Commission and is expressed as a percentage. Underwriter Reputation (MVGP) is the Migliorati and Vismara (2014) underwriter ranking using gross proceeds. Underwriter Reputation ( $C$-score) uses the credit scores assigned to an underwriter in the year prior to the IPO. Volatility (market) is the volatility of the FTSE AIM All Share Index during the two months prior to the IPO date. ***, ** and * indicate statistical significance at the $1 \%, 5 \%$ and $10 \%$ significance levels.

\begin{tabular}{|c|c|c|c|c|c|c|c|c|}
\hline & \multicolumn{2}{|c|}{$\begin{array}{c}\text { Warrants }=1 \\
(\mathrm{~N}=93)\end{array}$} & \multicolumn{2}{|c|}{$\begin{array}{c}\text { Warrants }=0 \\
(\mathrm{~N}=223)\end{array}$} & \multicolumn{2}{|c|}{$\begin{array}{c}\text { Total Sample } \\
(\mathrm{N}=316)\end{array}$} & \multirow{2}{*}{$\begin{array}{c}\text { Difference in } \\
\text { Means }\end{array}$} & \multirow{2}{*}{$\begin{array}{c}\begin{array}{c}\text { Difference in } \\
\text { Medians }\end{array} \\
\text { (p-value) }\end{array}$} \\
\hline & Mean & Median & Mean & Median & Mean & Median & & \\
\hline Underpricing (\%) & 23.20 & 10.60 & 14.3 & 9.20 & 17.00 & 9.70 & $0.06 *$ & 0.29 \\
\hline Issue Price (£) & 0.83 & 0.76 & 1.17 & 1.00 & 1.07 & 0.98 & $0.00 * * *$ & $0.00 * * *$ \\
\hline Public Float (\%) & 33.00 & 33.00 & 38.60 & 33.60 & 36.80 & 33.00 & $0.00 * * *$ & $0.00 * * *$ \\
\hline Standard Deviation (\%) & 3.10 & 2.00 & 2.40 & 1.70 & 2.60 & 1.80 & $0.00 * * *$ & $0.00 * * *$ \\
\hline Age (years) & 2.67 & 0.47 & 4.33 & 0.67 & 3.84 & 0.66 & $0.02 * *$ & $0.07 *$ \\
\hline Gross Proceeds (mil. £) & 11.40 & 6.50 & 22.20 & 10.10 & 19.04 & 9.50 & $0.00 * * *$ & $0.00 * * *$ \\
\hline Secondary Proceeds (\%) & 5.29 & 0.00 & 18.01 & 0.00 & 14.30 & 0.00 & $0.00 * * *$ & $0.00 * * *$ \\
\hline Firm Size (mil. £) & 43.10 & 20.60 & 53.97 & 32.90 & 50.80 & 28.10 & $0.07 *$ & $0.02 * *$ \\
\hline Cash (mil. £) & 1.99 & 0.16 & 2.91 & 0.60 & 2.60 & 0.46 & $0.03 * *$ & $0.02 * *$ \\
\hline Commission $(\%)$ & 3.50 & 3.30 & 3.30 & 3.25 & 3.40 & 3.30 & $0.06^{*}$ & $0.09 *$ \\
\hline Value of Warrants (\%) & 2.40 & 1.10 & & & & & & \\
\hline Total Underwriter Compensation (\%) & 5.90 & 4.80 & 3.30 & 3.25 & 4.10 & 3.60 & $0.00 * * *$ & $0.00 * * *$ \\
\hline Value of Warrants/Commission (\%) & 69.00 & 33.00 & & & & & & \\
\hline Underwriter Reputation (MVGP) & 0.065 & 0.036 & 0.0382 & 0.0176 & 0.046 & 0.033 & $0.07 *$ & $0.00 * * *$ \\
\hline Underwriter Reputation (C-score) & 79.92 & 90.00 & 72.76 & 84.00 & 74.87 & 87.00 & 0.29 & 0.37 \\
\hline
\end{tabular}


Table 2

Bottom and Top 10\% of underwriters (by gross proceeds)

Number of IPOs is the number of IPOs brought to the market by the given underwriter. Gross proceeds is the money raised from all the IPOs each underwriter advised. \% of IPOs is the number of IPOs the underwriter advised, expressed as a percentage of the total number of IPOs in the sample. \% gross proceeds is the gross proceeds each underwriter raised, expressed as a percentage of the total gross proceeds of the IPOs in the sample. \% of IPOs with warrants is the number of IPOs that granted warrants to the underwriter, divided by the total number of IPOs that the underwriter advised. \% of total number of IPOs with warrants is the number of warrants the underwriter received divided by the total number of IPOs in the sample that issued warrants. The underwriters are ranked according to the gross proceeds raised from the flotation.

\begin{tabular}{lccccccc}
\hline Underwriters & $\begin{array}{c}\text { Number } \\
\text { of IPOs }\end{array}$ & $\begin{array}{c}\text { Gross } \\
\text { proceeds } \\
\text { (mil. \&) }\end{array}$ & $\begin{array}{c}\text { Number } \\
\text { of IPOs } \\
\text { with } \\
\text { warrants }\end{array}$ & $\begin{array}{c}\% \text { of } \\
\text { IPOs }\end{array}$ & $\begin{array}{c}\text { \% gross } \\
\text { proceeds }\end{array}$ & $\begin{array}{c}\text { \% of IPOs } \\
\text { with } \\
\text { warrants }\end{array}$ & $\begin{array}{c}\text { \% of total } \\
\text { number } \\
\text { of IPOs } \\
\text { with } \\
\text { warrants }\end{array}$ \\
\hline Hoodless Brennan \& Partners & 1 & 0.36 & 1 & 0.32 & 0.006 & 100 & 0.00 \\
Nabarro Wells \& Co. & 1 & 0.38 & 1 & 0.32 & 0.006 & 100 & 1.08 \\
Peel Hunt \& Company & 1 & 0.40 & 0 & 0.32 & 0.007 & 0 & 1.08 \\
Astaire \& Partners & 1 & 1.08 & 1 & 0.32 & 0.018 & 100 & 1.08 \\
Allied Provincial Securities & 1 & 1.20 & 0 & 0.32 & 0.020 & 0 & 0.00 \\
\hline & & Top 10\% of underwriters & & & \\
\hline Seymour Pierce & 38 & 214.37 & 19 & 12.02 & 3.56 & 50.00 & 19.79 \\
Altium Capital & 11 & 291.20 & 2 & 3.48 & 4.84 & 18.18 & 2.15 \\
Numis Securities & 14 & 547.87 & 7 & 4.43 & 9.11 & 50.00 & 7.53 \\
Evolution Securities & 30 & 774.38 & 11 & 9.49 & 12.87 & 36.67 & 11.83 \\
Collins Stewart & 33 & 1136.78 & 17 & 10.44 & 18.90 & 51.52 & 18.28 \\
\hline
\end{tabular}




\section{Table 3}

Descriptive statistics for the 93 warrants issued to the underwriter(s)

Size of warrant is measured as (number of shares that can be purchased under the warrant)/(IPO shares). Value of warrant is obtained from the CEV model and is measured as a percentage of gross proceeds. Exercise/offer price is calculated as (price at which the warrant can be exercised)/(offer price). Time to expiration (years) is measured as the number of years between the date of listing on AIM and the expiration date of the warrant. Lock-in (years) is the time period during which the warrant cannot be exercised. Min and Max are the minimum and maximum values respectively.

\begin{tabular}{|c|c|c|c|c|c|}
\hline \multicolumn{6}{|c|}{ Panel A: All warrants } \\
\hline & $\begin{array}{c}\text { Size of } \\
\text { warrant }(\%)\end{array}$ & $\begin{array}{c}\text { Value of } \\
\text { warrant }(\%)\end{array}$ & Exercise/offer price & Time to expiration (years) & $\begin{array}{r}\text { Lock-in } \\
\text { (years) }\end{array}$ \\
\hline Mean & 6.50 & 2.40 & 1.02 & 3.80 & 0.87 \\
\hline Median & 3.70 & 0.90 & 1.00 & 3.00 & 1.00 \\
\hline Min & 0.20 & 0.00 & 0.55 & 1.00 & 0.25 \\
\hline Max & 133.20 & 25.10 & 1.62 & 21.00 & 2.50 \\
\hline $\mathrm{N}$ & 93 & 93 & 93 & 93 & 26 \\
\hline \multicolumn{6}{|c|}{ Panel B: Warrants with no lock-in period $(N=67)$} \\
\hline Mean & 5.30 & 2.30 & 1.01 & 3.90 & \\
\hline Median & 3.70 & 0.80 & 1.00 & 3.00 & \\
\hline \multicolumn{6}{|c|}{ Panel C: Warrants with lock-in period (N=26) } \\
\hline Mean & 9.60 & 2.50 & 1.04 & 3.56 & 0.87 \\
\hline Median & 3.90 & 1.50 & 1.00 & 3.00 & 1.00 \\
\hline \multicolumn{6}{|c|}{ Panel D: Warrants with an exercise price equal to the offer price $(\mathrm{N}=\mathbf{8 0})$} \\
\hline Mean & 7.00 & 2.60 & 1.00 & 3.82 & \\
\hline Median & 3.80 & 1.10 & 1.00 & 3.00 & \\
\hline \multicolumn{6}{|c|}{ Panel E: Warrants with an exercise price lower than the offer price $(\mathrm{N}=3)$} \\
\hline Mean & 3.00 & 1.40 & 0.80 & 5.33 & \\
\hline Median & 2.70 & 1.80 & 0.91 & 5.00 & \\
\hline \multicolumn{6}{|c|}{ Panel F: Warrants with an exercise price higher than the offer price $(\mathrm{N}=10)$} \\
\hline Mean & 3.90 & 0.80 & 1.25 & 3.20 & \\
\hline Median & 2.70 & 0.60 & 1.20 & 3.00 & \\
\hline
\end{tabular}

In Panel A, the maximum size of the warrants is $133.2 \%$ of the shares offered in the IPO as one company (Alltracel Pharmaceuticals plc) issued 825,843 shares and a warrant to subscribe for $1,100,000$ ordinary shares. CNG Travel Group plc issued warrants that could be exercised up to 21 years post-admission. 


\section{Table 4}

\section{Maximum likelihood estimation of the determinants of the issuance of warrants(reduced-form probit regression)}

The dependent variable is a dummy that takes the value of one if the firm issues warrants to its underwriter(s) and zero otherwise. Age is the number of years from incorporation to flotation and is calculated as the natural logarithm of one plus age: In (1+age). Standard Deviation is the standard deviation of the IPO company's returns over 20 days in the aftermarket. 1/Offer Price is the inverse of the offer price. Secondary Proceeds is the percentage of gross proceeds raised from the selling of existing shares and is calculated as (gross proceeds from existing shares/total gross proceeds). Public Float is the ratio of the total number of shares sold in the IPO divided by the outstanding shares. Cash/GP is the cash and cash equivalents, available the year prior to the IPO, divided by the gross proceeds. Firm size is the natural logarithm of the value of the firm at offer price. Underwriter Rep. (MVGP) is the Migliorati and Vismara (2014) underwriter ranking using gross proceeds. Underwriter Rep.(C-score) uses the credit scores assigned to an underwriter in the year prior to the IPO. Volatility (market) is the volatility of the FTSE AIM All Share Index during the two months prior to the IPO date. Hot-issue market captures the average underpricing in the last three months before the IPO. The standard deviation, public float, secondary proceeds, cash/gp, and volatility (market) are winsorised at the $1^{\text {st }}$ and $99^{\text {th }}$ percentiles respectively. We make use of robust standard errors. $* * *, * *, *$ indicate statistical significance at the $1 \%, 5 \%$ and $10 \%$ significance levels respectively.

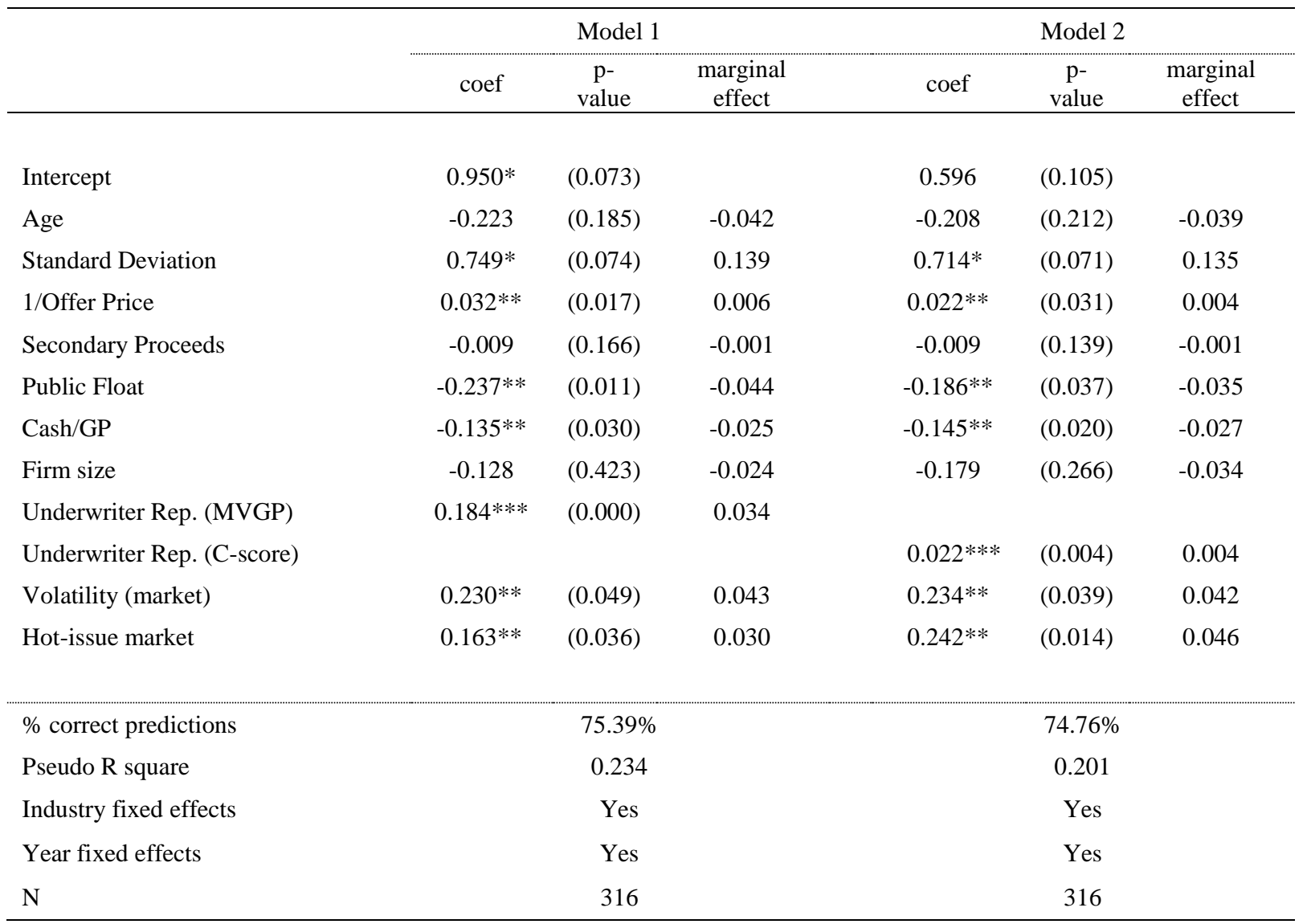


Table 5

\section{Second-stage regression estimates of the underpricing and total underwriter} compensation

Underpricing is the first-day return and is calculated as (closing price - issue price)/issue price. Total Underwriter Compensation is calculated as (Commission + Warrant Value)/Gross Proceeds. Age is the number of years from incorporation to flotation and is calculated as the natural logarithm of one plus age: ln (1+age). Standard Deviation is the standard deviation of the company's returns over 20 days in the aftermarket. 1/Offer Price is the inverse of the offer price. Secondary Proceeds is the percentage of gross proceeds raised from the selling of existing shares and is calculated as: (gross proceeds from existing shares/total gross proceeds). Public Float is the ratio of the total number of shares sold in the IPO divided by the outstanding shares. Cash/GP is the cash and cash equivalents, available the year prior to the IPO, divided by the gross proceeds. Firm Size is the natural logarithm of the value of the firm at offer price. Underwriter Rep. $(M V G P)$ is the Migliorati and Vismara (2014) underwriter ranking using gross proceeds. Volatility (market) is the volatility of the FTSE AIM All Share Index during the period two months prior to the IPO date. Hot-issue market captures the average underpricing in the last three months before the IPO. The standard deviation, public float, secondary proceeds, cash/gp, and volatility (market) are winsorized at the $1^{\text {st }}$ and $99^{\text {th }}$ percentiles respectively. We make use of robust standard errors.***,**,* indicate statistical significance at the $1 \%, 5 \%$ and $10 \%$ significance levels respectively.

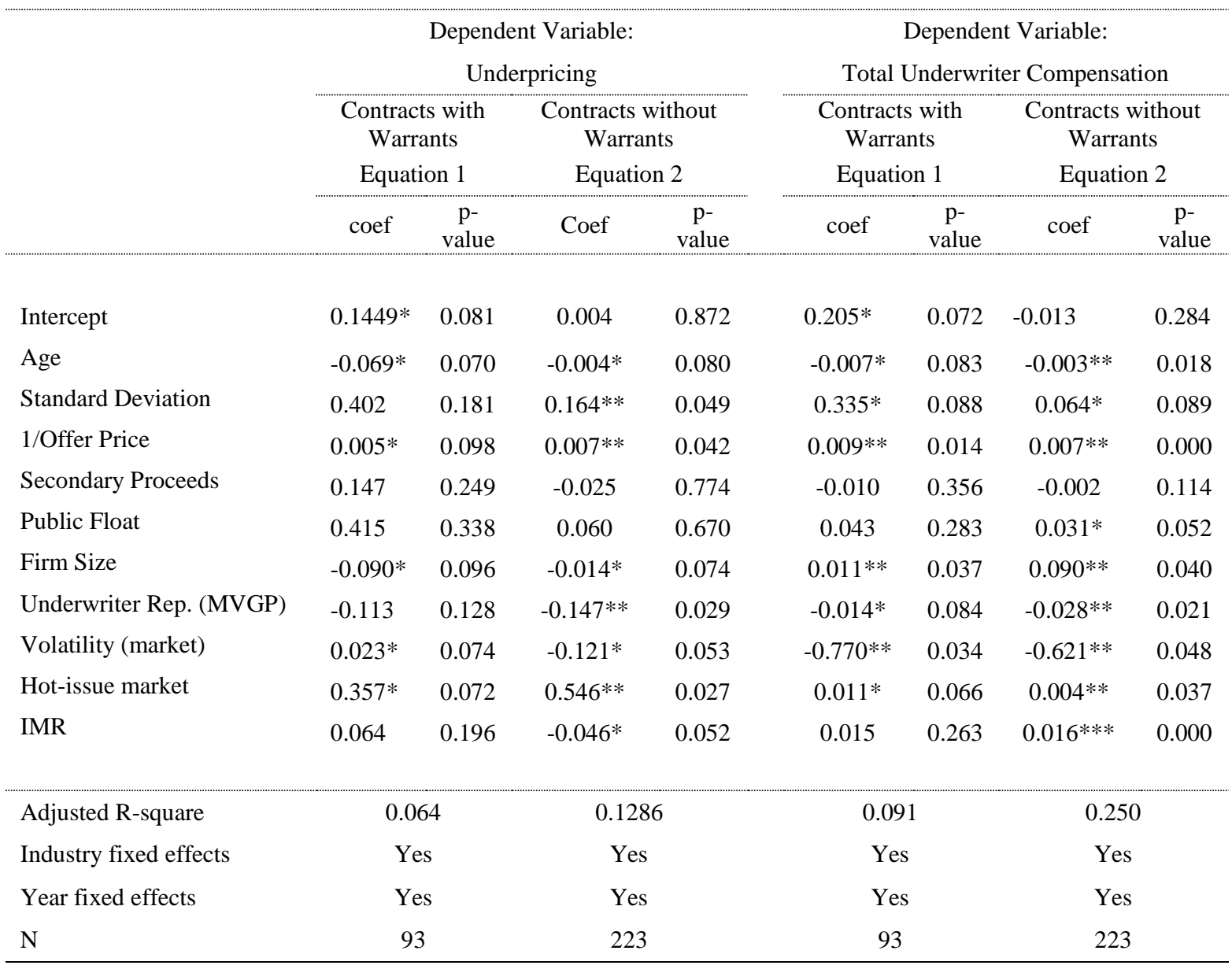


Table 6

Comparison of the actual IPO costs and the estimated IPO costs had the alternative compensation contract been used

This table compares the average underpricing and total underwriter compensation costs with the estimated costs had the alternative contract been used by the issuing firm. Underpricing is the first-day return and is calculated as (closing price - issue price) / issue price. Total Underwriter Comp. is the sum of the underwriter commission and value of warrants as a proportion of gross proceeds. $* * * * *$ and $*$ indicate statistical significance at the $1 \%, 5 \%$ and $10 \%$ significance levels.

\begin{tabular}{ccccccc}
\hline & \multicolumn{2}{c|}{$\begin{array}{c}\text { Average cost estimates for the 93 IPOs that } \\
\text { issued warrants to underwriters }\end{array}$} & \multicolumn{2}{c}{$\begin{array}{c}\text { Average cost estimates for the 223 IPOs that } \\
\text { did not issue warrants to underwriters }\end{array}$} \\
\cline { 2 - 7 } & $\begin{array}{c}\text { Actual } \\
\text { cost }\end{array}$ & $\begin{array}{c}\text { Estimated cost if } \\
\text { warrants had not been } \\
\text { issued to underwriter }\end{array}$ & $\begin{array}{c}\text { Difference } \\
\text { in means } \\
\text { p-value }\end{array}$ & $\begin{array}{c}\text { Actual } \\
\text { cost }\end{array}$ & $\begin{array}{c}\text { Estimated cost if } \\
\text { warrants had been } \\
\text { issued to underwriter }\end{array}$ & $\begin{array}{c}\text { Difference } \\
\text { in means } \\
\text { p-value }\end{array}$ \\
\hline $\begin{array}{c}\text { Underpricing } \\
(\%) \\
\text { Total }\end{array}$ & 23.20 & 29.69 & $0.00^{* *}$ & 14.30 & 21.10 & $0.00 * * *$ \\
$\begin{array}{c}\text { Underwriter } \\
\text { Comp. }(\%)\end{array}$ & 5.90 & 4.11 & $0.00^{* *}$ & 3.30 & 4.92 & $0.00 * *$ \\
\hline $\mathrm{N}$ & 93 & 93 & 223 & 223 & \\
\hline
\end{tabular}




\section{Appendix \\ Table A1 \\ Non-cash (i.e. warrants) and total underwriting compensation regulations: London Stock Exchange vs. US Stock Exchanges}

This table reports the main differences in the regulations underlying non-cash (i.e. warrant) and total underwriting compensation between the London Stock Exchange (LSE) and the US stock exchanges. The regulations underlying the warrant characteristics and the underwriting compensation are the same in the Alternative Investment Market (AIM) and the Main Market of the LSE, except for the amount of warrants that can be issued. The NASD and the New York Stock Exchange (NYSE) made amendments to Rule 2710 (Corporate Financing Rule) that became effective from 22 March 2004. The NASD and NYSE regulations were consolidated under the Financial Industry Regulatory Authority (FINRA) on 30 July 2007. FINRA adopted most of NASD Rule 2710 as FINRA Rule 5110 on 16 July 2008.

\begin{tabular}{ll}
\hline \multicolumn{1}{c}{ Rules } & \multicolumn{1}{c}{$\begin{array}{l}\text { London Stock Exchange } \\
\text { (Main and AIM markets) }\end{array}$} \\
\hline & $\begin{array}{l}\text { The amount of warrants } \\
\text { issued must be less than 10\% } \\
\text { of the company's share } \\
\text { capital on AIM (London }\end{array}$ \\
1. Amount of warrants offered & $\begin{array}{l}\text { Stock Exchange, 2007a). The } \\
\text { amount of warrants issued }\end{array}$ \\
to adviser (broker or Nomad) or \\
underwriter.
\end{tabular}

2. Exercise period.

3. Lock-in period.

4. Min. exercise price.

5. Min. value of warrants.

6. Max. limit on total underwriting compensation.

NA years (NASD Rule $\begin{aligned} & 5 \text { years } \\ & 5110) .\end{aligned}$
(FINRA Rule
NA $\quad \begin{aligned} & 1 \text { year (NASD Rule } \begin{array}{l}180 \text { days } \\ 2710) .\end{array} \\ & \text { NA (FINRA Rule } \\ & \text { Equal to the offer price } \\ & \text { (NASD Rule 2710). } \\ & \text { NA } \\ & \begin{array}{l}0.2 \% \text { of gross proceeds } \\ \text { for } 1 \% \text { amount of } \\ \text { warrants (NASD Rule } \\ 2710)\end{array}\end{aligned}$

Varies according to gross proceeds and risk assumed (NASD Rule 2710). NA
Varies according to gross proceeds and risk assumed (FINRA Rule 5110).

\section{US Stock Exchanges (before March 2004) \\ US Stock Exchanges (after March 2004)}

The amount of securities (i.e. warrants) issued to underwriters as part of their compensation cannot exceed $10 \%$ of the shares issued to the public (NASD Rule 2710). 2010a). NA 